\title{
Effects of Low dose Aroclor 1254 on Few Lysosomal Biomarker Enzymes from Liver and Brain of Mice under in vitro condition
}

\author{
Jalpa Raja ${ }^{1}$, Krishna Bhuva ${ }^{1}$, Shweta Pathak ${ }^{1}$ and Rahul Kundu ${ }^{1}$ \\ ${ }^{I}$ Department of Biosciences, Saurashtra University, Rajkot-360005, Gujarat State, INDIA.
}

\begin{abstract}
Aroclor 1254 contains very high concentration of chorine which makes it a persistent and toxic pollutant in the environment. The references of its toxic effects on liver and brain lysosomal biomarker enzymes are not abundantly available. Present study reports the possible dose and duration dependent toxic effects of low dose of Aroclor 1254 on few extracted lysosomal biomarker enzymes, acid phosphatase, $\alpha$ galactosidase, $\beta$-galactosidase and $\beta$-glucuronidase from liver and brain tissues of mice under in vitro condition. Two hypotheses were tested in the present study, (a) Aroclor 1254 has a dose and duration dependent effects on the activities of selected extracted enzymes and (b) the response exhibits an organ specific effect of the toxicant. The results revealed both significant exposure duration dependent and organ specific effects on the activities of lysosomal enzymes. The observed results indicated that if Aroclor 1254 enters into the cell and comes in direct contact with the lysosomal enzymes, it may influence the activities of the lysosome in a complex, organ specific way. Though the exact nature of the influences at cellular level is not clear, these may lead to an increase in the cellular accumulation of toxic substances which may contribute adverse toxic effects on the gross physiological conditions of the cell and the organism.
\end{abstract}

Keywords: PCB, Aroclor 1254, in vitro toxicity, lysosomal enzymes, liver, brain, mice

\section{Introduction}

PCBs are persistent environmental contaminants, which are highly chlorinated, highly lipophilic, and readily bioaccumulated in fatty tissues of all organisms. PCBs are found in the environment consist mainly of the highly chlorinated congeners of the original mixture, which are less susceptible to environmental degradation. Several mechanistic studies have either used individual congeners or reconstituted mixtures of various PCBs [1]. The primary route of exposure to PCBs in the general population reported to involve the consumption of contaminated foods, particularly meat, fish, and poultry [2]. PCBs as pollutants are persistent bioaccumulative and toxic chemicals hazardous to the environment for a long time and through food chain it exposed to the higher consumers including human [3]. Biological effects of polychlorinated biphenyls include inhibitory ones on the enzymatic systems and were investigated on laboratory animals, birds and fish $[4,5,6]$. PCBs and Dioxin-like PCBs are known to create the disturbances in the activities of lysosomal enzymes [7]. Lysosome plays an important role in the immune system and overall health of an organism. They also have other functional role such as intracellular digestion and recycling of macromolecules $[8,9]$. For the normal functioning of lysosomes the activities of lysosomal enzymes should be undisturbed. If the disturbances in the activities of lysosomal enzymes occur then there are fair chances of lysosomal destabilization. This lysosomal destabilization may result in the release of lysosomal enzymes into cytoplasm which leads to the potential adverse toxic effects on the cellular physiological processes of an organism. Disturbances in the activities of lysosomal enzymes are the efficient biomarker of lysosomal destabilization, can be used as an early warning tool to identify the toxic effects of many xenobiotic compounds [10]. Therefore, our present study was focused on the toxic effects of very low doses of Aroclor 1254 exposed for different time-intervals on few lysosomal biomarker enzymes in the liver and brain of mice under in vitro condition. The study tested two hypotheses whether, (a) Aroclor 1254 exhibits dose and time-interval dependent effects on the activities of selected lysosomal biomarker enzymes from the subcellular fractions and, (b) the response exhibits an organ specific effect of the toxicant to the selected enzyme.

\section{Materials and methods}

One of the PCBs, Aroclor 1254 in its purest form, was obtained from Sigma (CAS No. 1746-01-6) and used as toxicant. All other chemicals used in this study were of analytical grade. Healthy inbred male Swiss Albino mice, around 3 months of age and weighing $30 \pm 5 \mathrm{~g}$, were used for the entire study. The animals were fed with commercially available rodent diet and water ad libitum, and kept in the animal house facilities under hygienic condition as per CPCSEA India, guidelines. Humidity and temperature were controlled (25 \pm $2^{\circ} \mathrm{C}$ ) and diurnal cycle of $14: 10 \mathrm{~h}$ was maintained. All experiments were conducted according to norms and approval of CPCSEA, India (CPCSEA/CH/RF/ACK-2003, 29-07-2003). Known amount of whole liver and brain tissues were sampled from the tissues of animals and homogenized in chilled phosphate buffer (pH 7.0) to 
obtain a $10 \%(\mathrm{w} / \mathrm{v})$ homogenate. Enzyme extract preparation for purified lysosomal enzymes was carried out [11]. Homogenate was centrifuged at $2000 \mathrm{rpm}$ for $8 \mathrm{~min}$ at $4^{\circ} \mathrm{C}$. The obtained supernatant was re-suspended in phosphate buffer, centrifuged at $11,000 \mathrm{rpm}$ for 40 minutes and the resultant sediment was re-suspended in phosphate buffer with $0.1 \%$ Triton X 100 to obtain a supernatant of lysosomal fraction. The activity of Acid phosphatase, $\alpha$-galactosidase, $\beta$-galactosidase and $\beta$-glucuronidase were estimated using this lysosomal fraction extract [12]. However, before adding the respective substrate, enzyme aliquot was separately pre-incubated with selected doses $(25 \mu \mathrm{g} / \mathrm{ml}, 50 \mu \mathrm{g} / \mathrm{ml}$ and $100 \mu \mathrm{g} / \mathrm{ml})$ of Aroclor 1254 at room temperature for 15 and 30 minutes. In order to estimate the specific activities of the selected enzymes, protein content of the lysosomal fraction extract was estimated, using bovine serum albumin as standard [13]. Enzyme assay without Aroclor 1254 served as control. Obtained data were subjected to various statistical analyses like one-way and two-way nested ANOVA and Student's' $t$ ' test for their cumulative acceptability and hypothesis testing [14].

\section{Results and discussions}

Results of the present study showed the time interval dependent alterations in the specific activities of the lysosomal enzymes from liver and brain tissues of mice after exposed to the different doses of Aroclor 1254 for different time intervals under in vitro condition. In case of the liver tissue, inhibitory trend was observed in the activities of all the selected lysosomal enzymes. Specific activity of acid phosphatase showed inhibition after exposed for 15 and 30 minutes in different doses of Aroclor 1254. However, high degree of inhibition was observed after 30 minutes of exposure to different doses of Aroclor 1254 as compared to the control. While, $\alpha$ galactosidase activity showed the inhibitory trend after 15 and 30 minutes of exposure to different doses of Aroclor 1254, but highest and lowest inhibition was observed after 30 minutes and 15 minutes of exposure to various doses of Aroclor 1254 respectively. Whereas, the activity of $\beta$-galactosidase showed inhibitory trend after 15 and 30 minutes exposure in all the selected doses of Aroclor 1254 . The activity of $\beta$-glucuronidase showed inhibition after exposed to different doses of Aroclor 1254 for 15 and 30 minutes but high degree of inhibition was observed after 15 minutes exposure to Aroclor 1254 (Figure 1). In case of brain tissue, similar results were observed. A general inhibitory trend in the enzyme activity was observed, but the degree of enzyme inhibition was higher in the brain lysosomal fraction than that of liver. In case of acid phosphatase, the specific activity showed inhibitory trend in both the exposure durations after the exposure to various doses of Aroclor 1254. However, the degree of enzyme inhibition was found to be directly related to the exposure time. The specific activity of $\alpha$-galactosidase showed inhibition after exposure to different doses of Aroclor 1254 for both the exposure intervals, but the highest inhibition was observed in 15 minutes exposure duration. On the other hand, the specific activity of $\beta$-galactosidase showed exposure duration dependent inhibitory trend after the exposure to different doses of Aroclor 1254. Similar results were observed in case of $\beta$-glucuorindase (Figure 2).

Polychlorinated biphenyls (PCBs) are highly lipophilic substances which have the ability to bioaccumulate in the body fats, including cellular membranes of animals and humans. PCBs and Dioxin-like PCBs are known to alter the activities of lysosomal enzymes which may leads to lysosomal destabilization [7, 15]. Studies on molluscs showed that lysosomes were able to accumulate a diverse range of toxic metals and organic chemicals (e.g., PAHs, PCBs), which could destabilize the lysosomal membrane integrity [16]. Incubation of PCBs to rat liver lysosomes showed that this lipophilic substrate was highly active labilizers of lysosomal membranes [17]. The present study was designed to evaluate whether the direct contact of very low dose of Aroclor 1254 for various time-intervals, have any effects on liver and brain lysosomal biomarker enzymes of mice under in vitro condition.

The result of two-factor ANOVA after the exposure to three different doses $(25,50$ and $100 \mu \mathrm{g} / \mathrm{ml})$ of Aroclor 1254 for 15 and 30 minutes showed the significant alterations in the activities of few lysosomal enzymes under in vitro condition. In liver and brain tissue, the activities of acid phosphatase, $\alpha$-galactosidase, $\beta$ galactosidase and $\beta$-glucuronidase did not show the dose dependent significant alterations after the exposure to various doses of Aroclor 1254 but high time-interval dependent significant variations was observed. In case of acid phosphatase, exposure of Aroclor 1254 for both the time-interval exposure showed the high significant effects on the activities of selected lysosomal enzymes extracted from brain than in the liver. Similar kind of results was observed in the activities of $\alpha$-galactosidase and $\beta$-glucuronidase but in case of $\beta$-galactosidase, activity showed the high significant alterations in liver as compared to brain (Table 1). Results indicated that these alterations in the activities of the lysosomal enzymes could able to disturb functions of lysosomes such as, to eliminate foreign and endogenous molecules under stressed physiological conditions. This physiological condition could be responsible for the dysfunction of the cell degradation system [18, 19, 20]. Results of the single factor ANOVA showed significant alterations in the activities of all selected lysosomal enzymes of liver and brain after exposure to different doses of Aroclor 1254 for various exposure durations. The activity of acid phosphatase showed significant variations after exposure of $25 \mu \mathrm{g} / \mathrm{ml}$ dose of Aroclor 1254 in the liver extract, but in the brain tissue, the activity showed alterations after $50 \mu \mathrm{g} / \mathrm{ml}$ dose of Aroclor 1254. In case of $\alpha$ - 
galactosidase and $\beta$-glucuronidase, significant alterations in the specific activity was observed in $25 \mu \mathrm{g} / \mathrm{ml}$ in liver but did not show any significant variations in other two higher doses in liver tissue extract.

In the brain tissue extract however, significant variations were observed after exposure to all the doses of Aroclor 1254 for different time-intervals, but high significant alterations in the activities of the enzymes was observed after exposure to $25 \mu \mathrm{g} / \mathrm{ml}$ and $50 \mu \mathrm{g} / \mathrm{ml}$ dose of Aroclor 1254 to liver and brain respectively. The activity of $\beta$-galactosidase showed a general significant affects in liver and brain tissue extracts, but higher significant alterations was observed in $100 \mu \mathrm{g} / \mathrm{ml}$ dose to liver and $50 \mu \mathrm{g} / \mathrm{ml}$ dose to brain (Table 2). Results of the t-test between the control and individual treatment revealed significant alterations in the activities of selected lysosomal enzymes after exposure of different doses of Aroclor 1254 for both the exposure durations. In case of liver, specific activity of $\alpha$-galactosidase, $\beta$-galactosidase and $\beta$-glucuronidase showed the significant alterations in liver but the activity of acid phosphatase showed no significant dose and duration dependent alterations. Activity of $\alpha$-galactosidase showed the maximum changes after the exposure of $25 \mu \mathrm{g} / \mathrm{ml}$ and $100 \mu \mathrm{g} / \mathrm{ml} \mathrm{doses}$ exposed for 30 minutes and $50 \mu \mathrm{g} / \mathrm{ml}$ dose exposed for 15 minutes. While, the activity of $\beta$-galactosidase showed the highest alterations in $25 \mu \mathrm{g} / \mathrm{ml}$ and $50 \mu \mathrm{g} / \mathrm{ml}$ doses exposed for 30 minutes and in $100 \mu \mathrm{g} / \mathrm{ml}$ dose exposed for 15 minutes. Whereas, the activity of $\beta$-glucuronidase showed the maximum changes in $25,50 \mu \mathrm{g} / \mathrm{ml}$ doses exposed for 15 minutes and in $100 \mu \mathrm{g} / \mathrm{ml}$ dose of Aroclor 1254 exposed for 30 minutes. In case of brain tissue extract, the specific activity of acid phosphatase and $\beta$-galactosidase showed the significant changes in 25 $\mu \mathrm{g} / \mathrm{ml}$ and $100 \mu \mathrm{g} / \mathrm{ml}$ doses exposed for 30 minutes and in $50 \mu \mathrm{g} / \mathrm{ml}$ dose exposed for 15 minutes. However, the activity of $\alpha$-galactosidase showed maximum changes in all the doses exposed for 15 minutes. The activity of $\beta$ glucuronidase showed the maximum significant alterations in $25 \mu \mathrm{g} / \mathrm{ml}$ and $100 \mu \mathrm{g} / \mathrm{ml}$ doses of exposed for 15 minutes and in $50 \mu \mathrm{g} / \mathrm{ml}$ dose exposed for 30 minutes (Table 3 ).

Cytotoxic effects of PCBs or Dioxin like PCBs which may induce the oxidative stress are connected with the destabilizing of lysosomal membranes resulting in the release of lysosomal hydrolases into the cytosol with an induction of apoptosis or necrosis $[7,21,22,23,24]$. The present in vitro studies outlined the possibilities of the mechanism of toxic effects on few lysosomal biomarker enzymes extracted from liver and brain tissues of mice. In in vitro conditions, Aroclor 1254 comes in direct contact with the lysosomal enzymes and inhibit the activities while under in vivo condition, the toxicant is possibly comes into contact with the lysosomal enzymes via indirect ways. It is possible that the PCB passes through the cellular metabolic pathways and produces the hazardous metabolites which come into contact with these enzymes and induce the observed effects in the enzyme activity [7, 25]. The overall results of the present study revealed that these alterations in the activities of lysosomal enzymes of mice liver and brain may create the cellular disturbances that affect the normal functional activities of lysosomes such as intracellular digestion and recycling of macromolecules [2]. This could cause lysosomal destabilization and leads to the adverse physiological effects of the cells and tissue. Therefore, the results of the present study answer the hypotheses that exposure of Aroclor 1254 has timeinterval and organ-specific effects on the activities of lysosomal enzymes. The activities of lysosomal enzymes were more affected in brain tissue than the liver.

\section{Figures and Tables}

Table 1. Results of Two-Factor ANOVA between control and toxicated groups in Liver and Brain of mice.

\begin{tabular}{|c|c|c|c|c|c|c|c|c|}
\hline & \multicolumn{2}{|c|}{ Acid Phosphatase } & \multicolumn{2}{|c|}{$\alpha$-galactosidase } & \multicolumn{2}{|c|}{$\beta$-galactosidase } & \multicolumn{2}{|c|}{$\beta$-glucuronidase } \\
\hline & LIVER & BRAIN & LIVER & BRAIN & LIVER & BRAIN & LIVER & BRAIN \\
\hline Amongst doses & 0.28 & 0.15 & 0.97 & 1.68 & 1.34 & 0.27 & 0.15 & 2.59 \\
\hline Within durations & $6.73 *$ & $45.10^{*}$ & $49.01 *$ & $53.96 *$ & $97.81 *$ & $88.55^{*}$ & $24.99 *$ & $45.03 *$ \\
\hline
\end{tabular}

* Significant at $\mathrm{P}=0.05(\mathrm{~F}$ crit $(\mathrm{df}=3,7)=3.07)$

** Significant at $\mathrm{P}=0.05(\mathrm{~F}$ crit $(\mathrm{df}=7,31)=2.48)$

Table 2. Result of Single factor ANOVA between individual exposure durations within each group Liver and Brain of mice.

\begin{tabular}{lllllllll}
\hline & \multicolumn{2}{l}{ Acid Phosphatase } & \multicolumn{2}{l}{$\alpha$-galactosidase } & \multicolumn{2}{c}{$\beta$-galactosidase } & \multicolumn{2}{c}{$\beta$-glucuronidase } \\
\hline & LIVER & BRAIN & LIVER & BRAIN & LIVER & BRAIN & LIVER & BRAIN \\
Control & 3.63 & $28.73^{*}$ & $31.75^{*}$ & $50.53^{*}$ & 4.01 & $65.39^{*}$ & 0.48 & $14.98^{*}$ \\
$\mathbf{2 5} \boldsymbol{\mu g}$ & $32.75^{*}$ & $67.51^{*}$ & $16.97^{*}$ & $47.01^{*}$ & $45.61^{*}$ & $76.81^{*}$ & $20.31^{*}$ & $30.08^{*}$ \\
$\mathbf{5 0 \mu \mathrm { g }}$ & $28.95^{*}$ & $62.85^{*}$ & 0.06 & $22.81^{*}$ & $57.33^{*}$ & $82.47^{*}$ & 0.50 & $33.14^{*}$ \\
$\mathbf{1 0 0} \boldsymbol{\mu} \mathrm{g}$ & $11.07^{*}$ & $14.07^{*}$ & 0.33 & $28.28^{*}$ & $84.89^{*}$ & $20.91^{*}$ & 1.20 & $55.21^{*}$ \\
\hline
\end{tabular}

*Significant at $\mathrm{P}=0.05$ ( $\mathrm{F}$ crit. $=5.98)$ 
Table-3. Result of t-test between control and individual exposure duration within each dose.

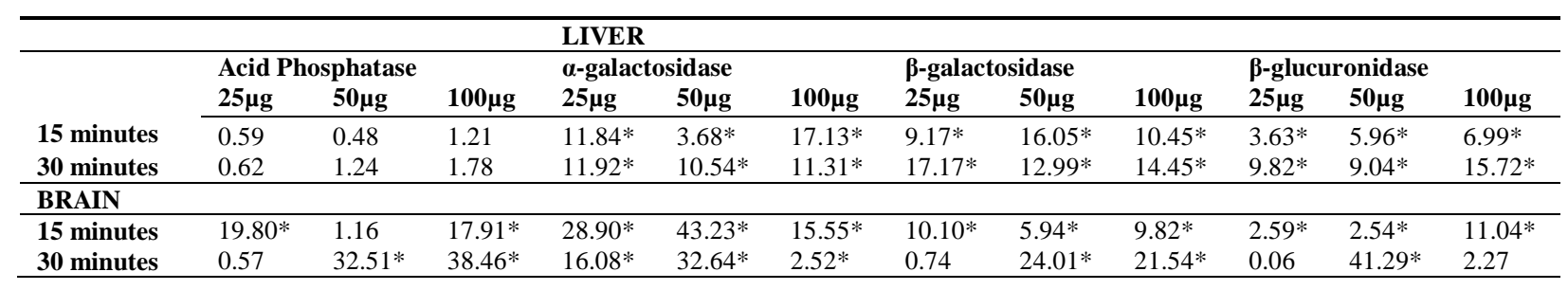

*Significant at $\mathrm{P}=0.05$ ( $\mathrm{T}$ crit. $=2.44$ )
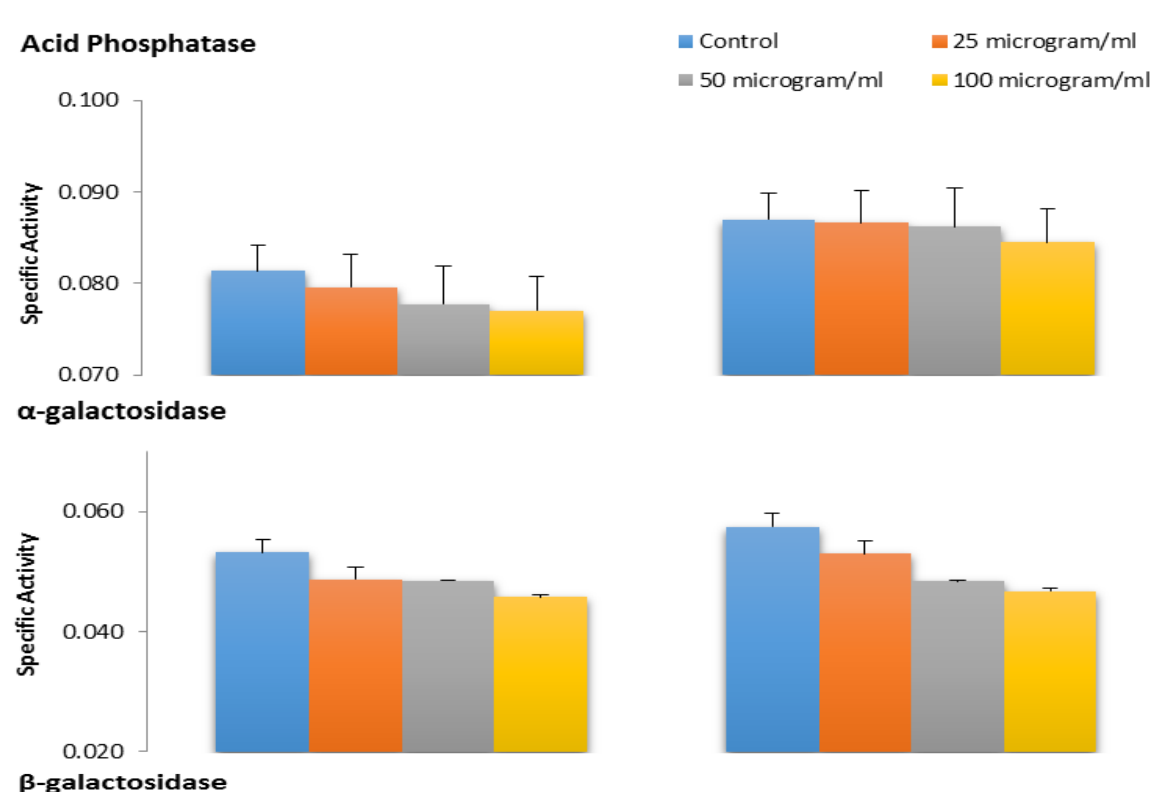

B-galactosidase

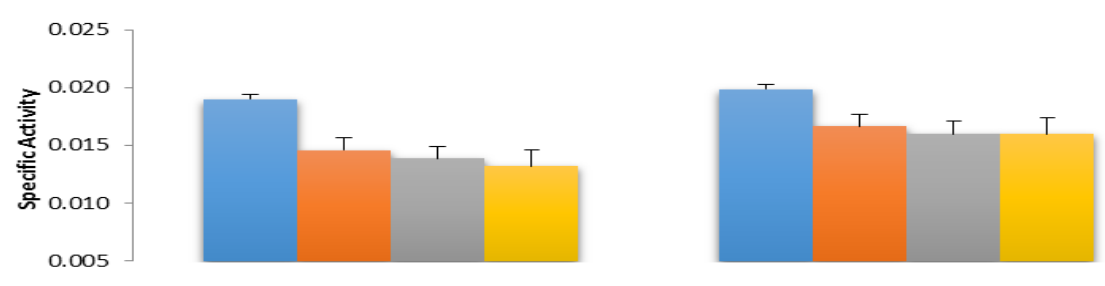

\section{$\boldsymbol{\beta}$-glucuornidase}

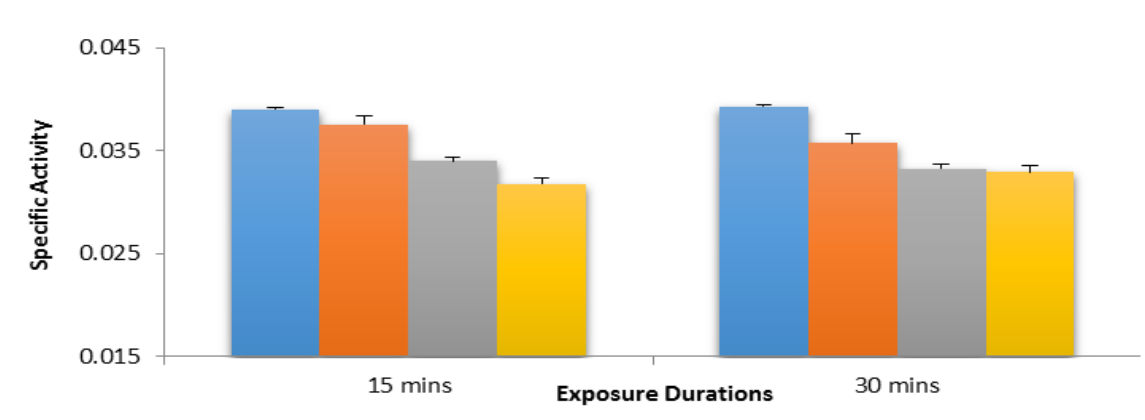

Figure 1. Dose and duration dependent variations in the specific activities of few lysosomal enzymes in the Liver tissue of mice after in vitro exposure of Aroclor 1254. 


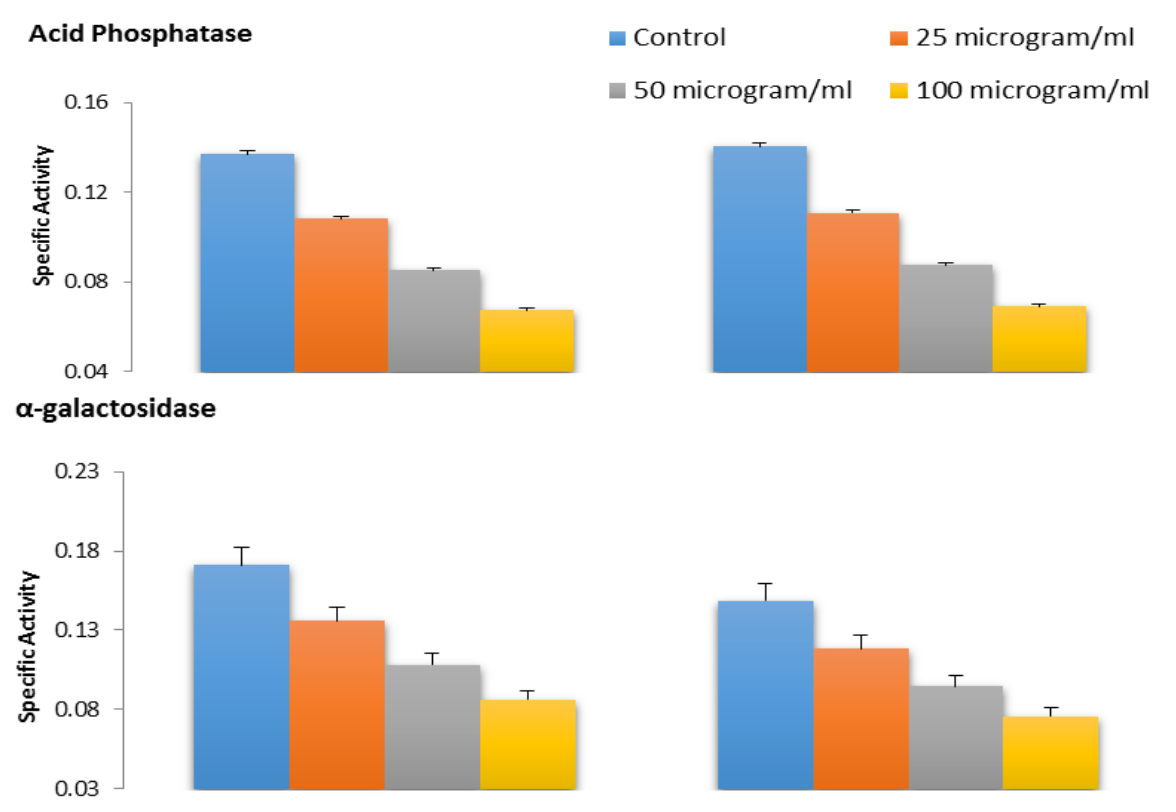

$\beta$-galactosidase

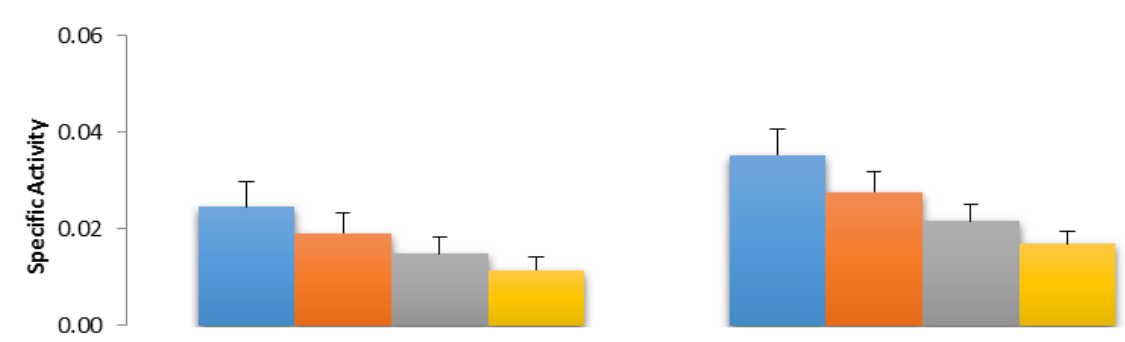

$\beta$-glucuronidase

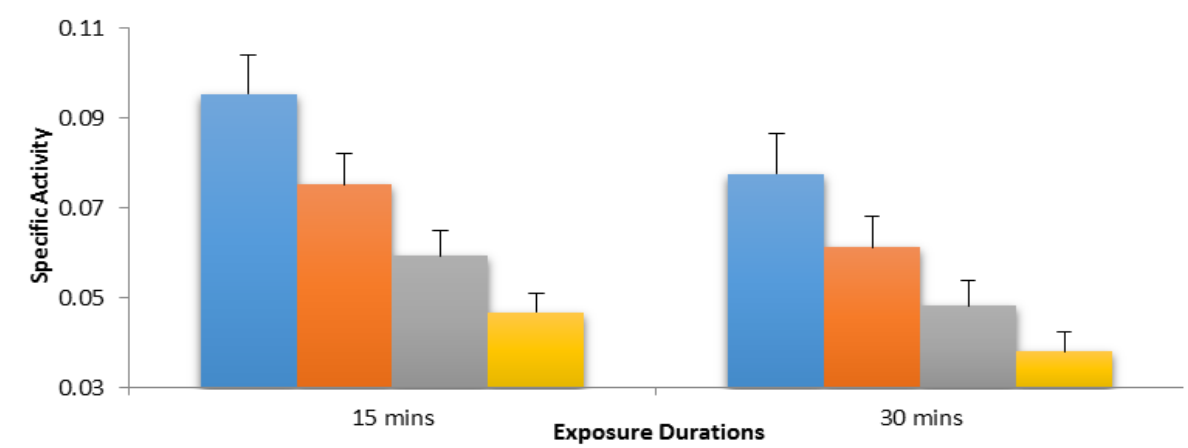

Figure 2. Dose and duration dependent variations in the specific activities of few lysosomal enzymes in the Brain tissue of mice after in vitro exposure of Aroclor 1254.

\section{Conclusion}

The present study revealed a predominantly time-interval dependent effects of the Aroclor 1254 on the few selected lysosomal enzymes in liver and brain of mice. However, the alterations in the lysosomal enzymes activity were clearly indicative of a direct and organ-specific effects of PCB in in vitro conditions. The overall results suggest that these alterations in the activities of lysosomal enzymes may cause lysosomal destabilization and leads to the adverse physiological effects of the cells and tissue as a whole in in vivo condition.

\section{Acknowledgements}

Authors are thankful to UGC, Govt. of India, New Delhi for supporting this study through its CAS programme sanctioned to the Department of Biosciences. 


\section{References}

[1]. Schantz, J.C. Gardiner, D.M. Gasior et al., Fine motor function in aging Great Lakes fish eaters, Health conference '97 Great Lakes \& St. Lawrence, Montreal, Quebec, Canada, 1997.

[2]. Agency for Toxic Substances and Disease Registry (ATSDR), Toxicological profile for polychlorinated biphenyls (update), Atlanta: US Department of Health and Human Services, 2000a.

[3]. S. Pathak and R. Kundu, Aroclor 1254 toxicity to mice liver membrane ATPases, Am. J. Pharma. Tox., vol. 8, no. 2, pp. 78-82, 2013 d.

[4]. S. Iwamoto, Effects of polychlorinated biphenyls on reproductive performance, Yamaguchi Igaku, vol. 31, pp. 193, 1982.

[5]. T. Ahmed, G.H. Arscott and I.J. Tinsley, Effect of chlorinated hydrocarbons on reproductive performance of adult white Leghorn male chickens, Sci., vol. 57, pp. 1594, 1978.

[6]. M. Perez-Lopez, M.C. Novoa-Valinas and M.J. Melgar-Riol, Glutathione S-transferase cytosolic isoforms as biomarkers of polychlorinated biphenyl (Arochlor 1254) experimental contamination in rainbow trout, Tox. Lett., vol. 136, pp. 97-106, 2002.

[7]. J. Jigyasi and R. Kundu, In vivo dose and duration dependent effects of Dioxin (2,3,7,8- TCDD) on few lysosomal enzymes in mice brain, IOSR J. Env. Sci. Tox. Food Tech., vol. 7, no. 3, pp. 69-73, 2013.

[8]. D.F. Bainton, The discovery of lysosomes, J. Cell Bio., vol. 91, pp. 66s, 1981.

[9]. B. Storrie, The lysosome: Its role in the biology of the cell and organism, In Bittar EE, Bittar eds, Principles of Medical Biology, JAI, New York, NY, USA, vol. 3, pp. 1-18, 1995.

[10]. H.M. Hwang, T.L. Wade and J.S. Sericano, Destabilized lysosomes and elimination of polyaromatic hydrocarbons and polychlorinated biphenyls in eastern oysters (Crassostrea viginica), Env. Tox. Chem., vol. 23, no. 8, pp. 1991-1995, 2004.

[11]. H. Beaufay, Methods for the isolation of lysosomes, In: J.T. Dingle, ed. Lysosomes: A Laboratory Handbook North-Holland Publ. Co. Amsterdam, 1972.

[12]. G. Tettamanti and M. Masserini, Beta mannosidase, In: Methods of Enzymatic Analysis III eds edited by Bergmeyer H.U. Verlag Chemie, Weinheim, Deerfield beach, Florida, Basel, 1984.

[13]. O.H. Lowry, N.J. Rosebrough, A.L. Farr et al., Protein measurement with the folin phenol reagent, J. Biol. Chem., vol. 193, no. 265-275, 1951.

[14]. R.R. Sokal and F.J. Rohlf, Biometry, W.H. Freeman and Company, San Francisco, pp. 260, 1969.

[15]. S. Pathak and R. Kundu, Low doses of a PCB (Aroclor 1254) affect the body weight by decreasing the activity of glucose-6phosphatases in the liver and kidney cells of mice, IOSR J. Env. Sci. Tox. Food Tech., vol. 3, no. 1, pp. 16-21, 2013b.

[16]. Environment Protection Department, EPD: Govt. Hong website http://www.epd.gov.hk/epd/english/environmentinhk/water/marine_quality/bio_lyso05.html. 2007.

[17]. S. Rogers, A. Mellors and S. Safe, Lysosomal membrane labilization by DDT, DDE and polychlorinated biphenyls (PCB), Res. Comm. Chem. Path. Pharma., vol. 13, no. 2, pp. 341-343, 1976.

[18]. A. Kołątaj, A. Śliwa -JoZwik and A. JoZwik, The lysosomal cell complex as a stress response indicator, Animal Science Papers and Reports, vol. 19, pp. 177-192, 2001.

[19]. A. Lankoff and A. Kołątaj, Influence of microcystin-YR and nodularin on the activity of some glucosidases in mouse liver, Tox., vol. 146, pp. 177-185, 2001 .

[20]. A. JoZwik, A. Śliwa -JoZwik, E. Bagnicka et al., The influence of selection on reaction to stress in mice, IX, Effect of dietary protein level on activity of lysosomal enzymes in liver and kidney, J. Ani. Breed. Gene., vol. 120, pp. 124-131, 2003.

[21]. K. Roberg, Relocalization of cathepsin D and cytochrome c early in apoptosis revealed by immunoelectron microscopy, Laboratory Investigation, vol. 81, pp. 149-158, 2001.

[22]. A. Sliwa -JoZwik, A. JoZwik and A. Kołątaj, The influence of vitamin E on the reactivity of lysosomal enzymes in cellular fractions of the mouse liver and kidney, In Polish, summary in English, Medycyna Weterynaryjna, vol. 58, pp. 28-284, 2002a.

[23]. A. Śliwa -JoZwik, A. JoZwik and A. Kołątaj, Influence of exogenous glutathione (GSH), as stress factor, on the activity of lysosome enzymes in some organs of mice, Archivfür Tierzucht, vol. 45, pp. 307-314, $2002 \mathrm{~b}$.

[24]. Y. Ogawa, T. Kobayashi and A. Nishioka et al., Reactive oxygen species-producing site in radiation-induced apoptosis of human peripheral t cells: involvement of lysosomal membrane destabilization, International J. Mole. Med., vol. 13, pp. 69-73,2004.

[25]. K. Bhuva K, J. Raja, S. Pathak, J. Jigyasi, S.K. Teraiya and R. Kundu, Alterations in the activities of few lysosomal enzymes in the kidney and intestine of mice exposed to low doses of a PCB, Aroclor 1254 under in vitro condition, IOSR J. Env. Sci. Tox. Food Tech., vol. 8, no. 2, pp. 89-94, 2014.

[26]. S. Pathak and R. Kundu, Short-term PCB (Aroclor 1254) toxicity on few phosphatases in mice brain, Dose Response, vol. 11, no. 1, pp. 1-8, 2013a. 